\title{
HIPERTERMIJOS IR DEHIDRATACIJOS POVEIKIS AKTYVIAI SPORTUOJANČIŲ VYRŲ GRIAUČIŲ RAUMENŲ NUOVARGIUI ATLIEKANT MAKSIMALAUS INTENSYVUMO IZOMETRINIUS KRŪVIUS
}

\author{
Kazys Vadopalas, Albertas Skurvydas, Marius Brazaitis, Laimutis Škikas, \\ Dalia Mickevičienè, Ieva Lukošiūtè-Stanikūnienè \\ Lietuvos kūno kultūros akademija, Kaunas, Lietuva
}

\begin{abstract}
Kazys Vadopalas. Medicinos mokslų magistras. Lietuvos kūno kultūros akademijos doktorantas. Lietuvos kūno kultūros akademijos Taikomosios fiziologijos ir sveikatos ugdymo katedros asistentas. Mokslinių tyrimų kryptis — raumenų fiziologija: hipertermijos ir dehidratacijos poveikis griaučių raumenų nuovargiui.
\end{abstract}

\section{SANTRAUKA}

Tyrimo tikslas - nustatyti hipertermijos ir dehidratacijos poveikì maksimaliajai valingai jejgai (MVJ) ir centriniam nuovargiui, ¿̇vertinti, kaip rehidratacija veikia hipertermijos salygomis griaučiu raumenu funkcijas atliekant 2 min maksimalu izometrini krūvi. Tiriamieji - suauge aktyviai sportuojantys vyrai $(n=10)$. Ju amžius $-21 \pm 1,3 \mathrm{~m}$.,

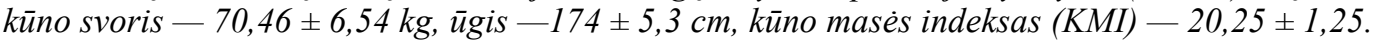

Atlikti trys tyrimai - vienas kontrolinis ir du eksperimentiniai. Vieno eksperimento metu buvo sukeliama organizmo hipertermija ir dehidratacija (tiriamieji 45 min sèdejo panire iki dubens šiltoje vonioje, kurios vandens temperatüra $-44 \pm 1{ }^{\circ} \mathrm{C}$ ). Kito eksperimento metu ta pačia metodika sukeliant hipertermija buvo atliekama peroralinè organizmo rehidratacija $1000 \mathrm{ml} 37^{\circ} \mathrm{C} \mathrm{NaCl} \mathrm{0,9 \%} \mathrm{tirpalu.} \mathrm{Maksimalus} \mathrm{valingos} \mathrm{jeggos} \mathrm{(MVJ)} \mathrm{izometrinis} \mathrm{krūvis}$ tęsèsi $120 \mathrm{~s}$ : kas 15 s raumuo buvo stimuliuojamas elektros impulsais - stimuliacijos trukmé $250 \mathrm{~ms}$, dažnis $100 \mathrm{~Hz}$, itampos dydis 85-105 V. Registruotas maksimaliosios valingos jègos momentas $(\mathrm{N} \cdot \mathrm{m})$ ir centrines aktyvacijos koeficientas $(C A R \%) . C A R \%=$ MVJ $/(M V J+$ elektrinis impulsas $) \times 100$. Tiriamieji krūvio metu buvo motyvuojami verbaliniu büdu, suteikiant jiems vizualia jègos signalo kitimo informacija. Sukèlus hipertermija ir dehidratacija, rektaline kūno temperatūra vidutiniškai padidejo nuo $37,38 \pm 0,25$ iki $39,36 \pm 0,32{ }^{\circ} \mathrm{C}(p<0,001)$, atlikus rehidratacija hipertermijos salygomis - nuo 37,22 $\pm 0,25$ iki 39,32 $\pm 0,4^{\circ} \mathrm{C}(p<0,001)$. Hipertermijos eksperimento metu tiriamieji vidutiniškai neteko $0,94 \pm 0,15 \mathrm{~kg}$, ir tai sudarè $1,33 \pm 0,13 \%$ küno svorio ( ${ }^{\circ}$ dehidratacija). Išanalizavus fiziologini šilumos streso indeksq (10 balu sistema) nustatyta, kad tiriamieji patyré aukšto lygio fiziologiní stresa

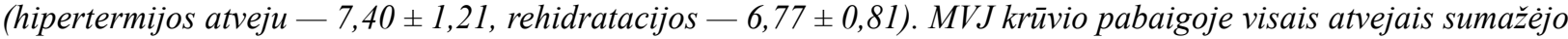
reikšmingai $(p<0,001)$, palyginti su prieš krūvį nustatytais rodikliais. Atsigavimo metu, praèjus 15 s po krūvio, jèga grǐž ì pradini lygi.

Dvieju veiksniu dispersinè analizè atskleidè, kad analizuojamu jègos rodikliu pokytis priklausè nuo laiko $(p<0,001)$, o hipertermijos dydžio ir sqveikos tarp ju rezultato reikšmingai nepaveike ( $p>0,05)$. Išanalizavus valingo aktyvavimo rodiklius pastebèta, kad hipertermija $(p<0,001)$ ir rehidratacija $(p<0,05)$ reikšmingai sumažino raumenu centrinès aktyvacijos koeficienta (CAR\%), palyginti su prieš krūvi nustatytu. Atsigavimo metu, praèjus 15 s po krūvio, CAR\% buvo toks pat kaip ir prieš krūvi. Atlikus dvieju veiksniu dispersinę analizę nustatyta, kad analizuojamu centrinès aktyvacijos jègos rodikliu pokytis priklausè nuo laiko $(p<0,001)$ ir squeikos tarp büsenos bei laiko $(p<0,01)$, o būsena rezultato reikšmingai nepaveikè $(p>0,05)$. Taikant pasyvaus raumenu šildymo metodika, buvo sukelta tiriamuju organizmo hipertermija ir $I^{\circ}$ dehidratacija. Hipertermija padidino centrini nuovargi. Hipertermijos ir rehidratacijos eksperimentu metu MVJ nuovargis kito vienodai. Rehidratacija hipertermijos salygomis sumažino centrini nuovargi atliekant 2 min maksimalu izometrini krūvi.

Raktažodžiai: hipertermija, izometriniai pratimai, dehidratacija, rehidratacija, centrinis nuovargis.

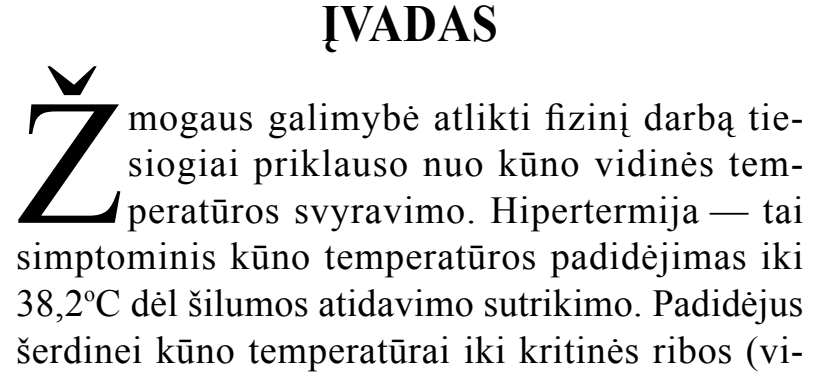

dutinio fizinio aktyvumo asmenu $-38,7 \pm 0,2^{\circ} \mathrm{C}$, didelio meistriškumo $\left.-39,2 \pm 0,1^{\circ} \mathrm{C}\right)$, žmogaus kūnas perkaista, atsiranda nuovargis. Nustatyta, kad kūno šerdinès temperatūros padidejimas iki $39^{\circ} \mathrm{C}$ yra kritinis centrinès nervu sistemos nuovargiui (Todd et al., 2004). Hipertermija padidina 
fiziologinę kūno įtampą, kurios metu gali smarkiai sumažèti fizinis darbingumas, vedantis prie išsekimo, perkaitimo, traumos ir netgi mirties. Daugelis gyvūnu atsisako fizinès veiklos tol, kol jų šerdinė temperatūra pasiekia saugią ribą. Literatūroje nuolatos keliama hipotezè, kad pavojingai aukšta vidinè kūno temperatūra tiesiogiai padidina nuovargi ir pagreitina išsekimą. Pastaroji tema yra plačiai nagrinejjama, tačiau esminiai mechanizmai nèra iki galo išsiaiškinti (Morrison et al., 2004). Hipertermijos sąlygomis fizinis darbingumas sumažèja dèl ašinès temperatūros padidejjimo iki kritinès ribos (Cheung, McLellan, 1998), kuriai esant suaktyvinamos termoreguliacijos ir širdies kraujagyslių sistemos (Rowell, 1974). Hipertermijos sąlygomis atsiranda vietinių raumens pokyčių, padidèja raumenu susitraukimo ir atsipalaidavimo greitis (De Ruiter, De Hann, 2000). Hipertermija gali tiesiogiai veikti raumenu valingą aktyvavimą - temperatūra motoriniame vienete pakeičia impulso dažni, reikalingą tetaniniam susitraukimui (Todd et al., 2004).

Kuri laiką buvo manoma, kad mechanizmas, paaiškinantis neuroraumenini nuovargi, hipertermijos sąlygomis gali kilti tiek dèl centrinès, tiek dèl periferinès nervu sistemos pokyčiu (KentBraun, 1999). Tačiau M. M. Thomas ir kt. (2006) tyrimu ịodè, kad hipertermija sumažino neuroraumenini darbinguma, ir tai priklausè nuo centrinès nervų sistemos negalëjimo gerai aktyvuoti raumens, o vietiniai raumens pokyčiai tam tiesioginès itakos neturejo. Nustatyta, kad padidejus raumenu temperatūrai iki $38,6^{\circ} \mathrm{C}$ izometrinè raumenų jèga sumažèja, kai pratimai atliekami panašia absoliučia jèga (Cheung, Sleivert, 2004).

Hipertermijos metu vykstanti temperatūrinè homeostazè didina prakaitavimą ir širdies kraujagysliu sistemos darbą (Armstrong, 2000). Priežastis, dèl kurios gali sumažèti raumenų fizinis darbingumas, yra skysčių netekimas organizme dehidratacija. K. Vadopalas ir kt. (2007), taikydami pasyvaus raumenų šildymo metodiką, sukèlè nesportuojančiu vyrų organizmo hipertermiją ir $\mathrm{I}^{\mathrm{o}}$ dehidratacija. Hipertermijos metu netekus $2 \%$ kūno svorio, žmogaus ištvermė sumažeja $22 \%$, o netekus 4\% - net 48\% (Armstrong et al., 1992). Dirbant karšto klimato sąlygomis ar atliekant didelio intensyvumo ilgos trukmès fizinius pratimus, žmogus vidutiniškai netenka $0,8-1,41$ / h prakaito (Armstrong, 2000). Aklimatizuoti žmonès kartu su prakaitu netenka apie $0,8-2,0 \mathrm{~g} \mathrm{NaCl} / 1$, o neaklimatizuoti - apie 3,0-4,0 g NaCl / 1 (Armstrong, 2000). Pastarieji elektrolitai žmogaus or- ganizme yra laikomi pagrindiniais, kurių dèka palaikoma vandens pusiausvyra viduląstelineje ir tarpląstelinejje terpejje, nervinis laidumas, ląstelinis metabolizmas ir kraujo tūris - osmoreguliacija ir spaudimas (Armstrong, 2000). Maksimalus skysčiu kiekis, kurị fiziškai aktyvių žmonių organizmas gali pasisavinti, yra apie $0,8-1,21 / \mathrm{h}$ (Coyle, Hamilton, 1990). Rehidratacija hipertermijos sąlygomis gali padidinti nesportuojančių vyrų organizmo centrini nuovargi, atliekant 2 min maksimalu izometrini krūvį (Vadopalas ir kt., 2007).

Iki šiol literatūroje nepavyko rasti duomenų, irodančiu, kaip per 45 min pasyviai sukelta hipertermija ir dehidratacija veikia aktyviai sportuojančių vyrų raumenų funkcini pajègumą, nėra iki galo aiškus rehidratacijos poveikis hipertermijos sąlygomis, kai atliekami maksimalaus intesyvumo izometriniai pratimai.

Tyrimo tikslas - nustatyti hipertermijos ir dehidratacijos poveiki MVJ ir centriniam nuovargiui, išaiškinti, kaip rehidratacija veikia hipertermijos sąlygomis aktyviai sportuojančių vyrų griaučių raumenų funkcijas atliekant 2 min maksimalu izometrini krūvi.

\section{TYRIMO METODAI IR ORGANIZAVIMAS}

Tiriamieji - sveiki aktyviai sportuojantys vyrai (vidutinių nuotolių bėgikai, sportuojantys $10 \mathrm{~h}$ per savaitę $(\mathrm{n}=10))$. Jų amžius $21 \pm 1,3$ m., kūno masè $-70,46 \pm 6,54 \mathrm{~kg}$, ūgis $174 \pm 5,3 \mathrm{~cm}, \mathrm{KMI}-20,25 \pm 1,25$. Tiriamieji buvo supažindinti su tyrimo tikslais, procedūra ir galimais nepatogumais. Norą dalyvauti tyrime jie patvirtino raštu. Tyrimas atliktas laikantis $1975 \mathrm{~m}$. Helsinkio deklaracijoje priimtu principu dèl eksperimentų su žmonėmis etikos. Tyrimo protokolas aptartas ir patvirtintas Kauno regioniniame biomedicininių tyrimų etikos komitete (Protokolo Nr. 130/2005; Leidimo Nr. BE-2-54).

Dinamometro nustatymas ir padèties sureguliavimas. Izometrinè blauzdos tiesiamujų raumenu jèga vertinta naudojant izokinetini dinamometra (Biodex Medical System 3, New York). Tiriamieji buvo sodinami i dinamometro įrenginio kèdę, testuojama dešinè koja. Prie dinamometro pritvirtinamas papildomas blauzdos tvirtinimo itaisas. Nustatoma kelio anatomine sąnario ašis ir sulyginama su dinamometro dianaminès apkrovos mazgo ašimi. Nustatoma visa kelio sąnario amplitude (blauzdą ištiesus $0^{\circ}$ ir sulenkus $115^{\circ} \mathrm{kampu}$ ). Mažinant viso kūno inercini svyravimą, tiriamasis 
apjuosiamas pečių, liemens ir šlaunies diržais. Blauzda sutvirtinama diržu virš kulnakaulio gumburo ties apatiniu trečdaliu, koja fiksuojama per kelio sąnari 90 ir $60^{\circ} \mathrm{kampu}$, pasveriama tada, kai ji fiksuota $72 \pm 5^{\circ} \mathrm{kampu}$ (gravitacinès sunkio jègos momentu). Valdymo skyde pasirenkamas izometrinis režimas. Registruota maksimalioji valinga raumenų susitraukimo jèga.

Eksperimento logika. Prieš eksperimentą buvo atliekamas žvalgomasis tyrimas, kurio metu tiriamieji turejjo priprasti prie laboratorijos aplinkos sąlygu ir pasimokyti atlikti didžiausio valingo izometrinio raumenų susitraukimo krūvị. Ne anksčiau kaip po savaitès tiriamieji, atrinkti atsitiktiniu būdu, atliko kontrolini arba vieną iš eksperimentinių tyrimų.

Atlikti trys tyrimai - vienas kontrolinis ir du eksperimentiniai. Kontrolinio tyrimo metu tiriamieji po neintensyvios pramankštos $-10 \mathrm{~min}$ bėgimo (pulso dažnis $110-130 \mathrm{tv}$. / min) — buvo sodinami i specialią izokinetinio dinamometro kẻdę ir atliko testavimą pagal tą pati protokolą, tik pasyviai raumenų nešildant.

Pirmas eksperimentinis tyrimas nuo kontrolinio skyrèsi tuo, kad jo metu vietoj pramankštos buvo pasyviai sukeliama hipertermija. Antro eksperimento metu ta pačia metodika sukeliant hipertermija, buvo atliekama peroralinè organizmo rehidratacija $1000 \mathrm{ml} 37^{\circ} \mathrm{C}$ (kūno temperatūros) fiziologiniu $\mathrm{NaCl} 0,9 \%$ tirpalu.

Taikant pasyvaus šildymo metodika, tiriamieji, atvykę i laboratorija, 30 min ramiai sẻdèdavo iprastinès temperatūros kambaryje $\left(20-22^{\circ} \mathrm{C}\right)$. Paskui buvo matuojama jų rektalinė temperatūra. Vèliau atliekamas kontrolinis MVJ matavimas, t. y. darant 2 min pertrauką atlikti trys maksimalūs valingi raumenų susitraukimai tiesiant blauzdą per kelio sąnari $120^{\circ}$ fiksuotu kampu (raumenu susitraukimo trukmé - 5 s). Maždaug 2-3 susitraukimų sekundę keturgalvis šlaunies raumuo buvo stimuliuojamas $100 \mathrm{~Hz}$ dažnio ir $250 \mathrm{~ms}$ trukmès elektriniu impulsu serija. Paskui kojos buvo šildomos pasyviai, iš karto po šildymo vèl matuojama rektalinè temperatūra. Išlipus iš vonios, ne vèliau kaip po $5 \mathrm{~min}$, tiriamasis buvo sodinamas i specialią dinamometro kède ir turèjo atlikti 2 min trukmès maksimalaus valingo izometrinio raumenu susitraukimo krūvị (MVJ-2 min). Praejjus 15 ir $300 \mathrm{~s}$ po krūvio, buvo atliekamas kontrolinis testavimas. Krūvio metu tiriamasis vilkèjo šiltą ilgą sportinę aprangą, buvo užsidejjęs pirties kepurę (hipertermijai išlaikyti eksperimentinių tyrimų metu). Abiejų eksperimentu pabaigoje buvo matuojama rektalinè temperatūra (hipertermijai kontroliuoti).
MVJ-2 min. Maksimalus valingas izometrinis krūvis truko $120 \mathrm{~s}$. Kas $15 \mathrm{~s}$ per odą elektriniu impulsu buvo stimuliuojamas šlaunies nervas, naudojant aukštos ittampos stimuliatorių (modelis MG440, Medicor, Budapest, Hungry). Stimuliacijos trukmè $-250 \mathrm{~ms}$, dažnis $-100 \mathrm{~Hz}$, itampos dydis - 85-105 V. Ittampos dydis buvo parenkamas individualiai kiekvienam tiriamajam. Elektrinio impulso itampa didinama tol, kol nevalinga raumenų izometrinio susitraukimo jèga pasiekdavo $70-75 \%$ maksimaliosios jègos (stimuliacijos trukmè - $1 \mathrm{~s}$, dažnis - $100 \mathrm{~Hz})($ Nybo, Nielsen, 2001). Registruotas maksimaliosios valingos jègos momentas $(\mathrm{N} \cdot \mathrm{m})$ ir centrinis aktyvacijos koeficientas (CAR\%). Tai yra tiesioginis rodiklis, nusakantis raumenų aktyvacijos dydį iš CNS (Enoka, 2002). $\mathrm{CAR} \%=\mathrm{MVJ} /(\mathrm{MVJ}+$ elektrinis impulsas $) \times 100$ (Kent-Braun, 1996; Enoka, 2002). Kuo didesnis CAR\%, tuo centrinis nuovargis mažesnis $(100 \%$ rodo visišką raumenų aktyvaciją). Tiriamasis krūvio metu buvo motyvuojamas verbaliniu būdu, suteikiant jam vizualią jègos signalo kitimo informacija.

Pasyvaus šildymo metodika. Tiriamieji sèdèdami 45 min laikè kojas šiltoje vonioje, kurios vandens temperatūra $-44 \pm 1^{\circ} \mathrm{C}$, kambario temperatūra $20-22^{\circ} \mathrm{C}$. Šildymo metu jie negalejo vartoti jokiu gèrimu ar naudoti dirbtinio vèsinimo irenginiu. Šildymo pabaigoje testuojamo raumens temperatūra $3 \mathrm{~cm}$ gylyje padideja $\sim 2,7^{\circ} \mathrm{C}$ (Sargeant, 1987). Vandens temperatūra buvo matuojama vandens termometru, patalpos - oro termometru.

Rektalinès temperatūros matavimo metodika. Rektalinè temperatūra buvo matuojama zondu, apvilktu silikonine guma su imontuotu termodavikliu (Ellab, tipas Rectal probe, Danija). Tiriamasis prieš pasyvų šildymą ir po jo issikišdavo zondą su termodavikliu i išeinamają angą (matavimo laikas - $10 \mathrm{~s}$, zondo gylis $-12 \mathrm{~cm}$ ) (Proulx et al., 2003). Zondas su termodavikliu po panaudojimo buvo sterilizuojamas autoklave.

Širdies ir kraujagyslių sistemos būsenos vertinimas. Pasyvaus šildymo metu širdies susitraukimų dažnis buvo registruojamas $5 \mathrm{~s}$ intervalais pulso matuokliu „Polar 625 x“ (Suomija).

Fiziologinio streso (šilumos) indekso (FSI) matavimo metodika. FSI buvo apskaičiuotas pagal formulę (Moran et al., 1998):

$$
\begin{aligned}
& \text { FSI }=5\left(\mathrm{~T}_{\text {rektalinè } t}-\mathrm{T}_{\text {rektalinè } 0}\right) \times\left(39.5-\mathrm{T}_{\text {rektalinè } 0}\right)^{-1} \\
& +\left(\check{\mathrm{SSD}}_{t}-\breve{\mathrm{SSD}}_{0}\right) \times\left(180-\mathrm{S}_{\mathrm{S}} \mathrm{T}_{0}\right), \\
& \text { čia }-\mathrm{T}_{\text {rektalinè } 0} \text { ir } \breve{S} S D_{0} \text { - pradiniai matavimai; } \mathrm{T}_{\text {rektalinè t }} \text { ir } \\
& \breve{S S D}_{\mathrm{t}} \text { - per tam tikrą laiką pasikartojantys matavimai. }
\end{aligned}
$$


FSI vertinimas: streso nèra arba labai mažas ( $0-2$ balai), žemas ( $3-4$ balai), vidutinis $(5-6$ balai), aukštas ( $7-8$ balai) ir labai aukštas $(9-10$ balu).

Rehidratacija. Nustatyta, kad hipertermijos metu žmogaus organizmas vidutiniškai netenka 0,8-1,4 1 prakaito, kur viename litre randama nuo 0,8 iki $4 \mathrm{~g} \mathrm{NaCl}$. Žmogaus organizmas per valanda gali pasisavinti apie $0,8-1,21$ skysčiu (Armstrong et al., 1986; Armstrong, 2000). Norint atgauti prarastą skystị, tiriamiesiems 15 min prieš pasyvų šildymą buvo duodama gerti fiziologinio $(0,9 \% \mathrm{NaCl}) 37^{\circ} \mathrm{C}$ (kūno temperatūros) tirpalo. Per $60 \mathrm{~min}$ tiriamieji lètai išgerdavo $1000 \mathrm{ml}$ skysčio (po $100 \mathrm{ml}$ kas $6 \mathrm{~min}$ ). Prieš tyrimą ir po jo nuogi vyrai (sausu kūnu) buvo sveriami elektroninèmis svarstyklèmis „Tanita TBF 300“ (Jungtinès Amerikos Valstijos). Nustatytas svorio skirtumas parode skysčių kieki, kurio neteko tiriamasis. Tiriamieji laikotarpiu tarp svèrimų negalèjo šlapintis ir vartoti skysčių.

Matematinė statistika. Buvo apskaičiuojami rodikliu aritmetinis vidurkis ir standartinis nuokrypis. Širdies ir kraujagyslių sistemos rodiklių kaitos priklausomumas nuo hipertermijos ir laiko buvo analizuojamas naudojant dviejų veiksnių dispersinę analizę. Skirtumo tarp aritmetinių vidurkių reikšmingumas nustatytas pagal dvipusį nepriklausomų imčių Studento $t$ kriterijų. Skirtumas statistiškai reikšmingas, kai $\mathrm{p}<0,05$.

\section{REZULTATAI}

Sukèlus hipertermiją ir dehidrataciją, rektalinẻ kūno temperatūra vidutiniškai padidèjo nuo $37,38 \pm 0,25$ iki $39,36 \pm 0,32^{\circ} \mathrm{C}(\mathrm{p}<0,001)$, atlikus rehidrataciją hipertermijos sąlygomis - nuo $37,22 \pm 0,25$ iki $39,32 \pm 0,4^{\circ} \mathrm{C}(\mathrm{p}<0,05)$ (1 pav.). Hipertermijos eksperimento metu tiriamieji vidutiniškai neteko $0,94 \pm 0,15 \mathrm{~kg}$, ir tai sudare $1,33 \pm 0,13 \%$ kūno svorio ( ${ }^{\circ}$ dehidratacija). Atlikus peroralinę rehidrataciją hipertermijos sąlygomis, tiriamujų kūno svoris vidutiniškai padidejo $0,1 \pm 0,42 \mathrm{~kg}$, ir tai sudare $0,1 \pm 0,58 \%$ jų kūno svorio. Pastarieji rodikliai rodo, kad organizmo rehidratacija atlikta iki galo. Išanalizavus fiziologini karščio streso indeksą (10 balų sistema) nustatyta, kad tiriamieji patyrè vidutinio lygio fiziologini stresą: hipertermijos tyrimo metu $-7,40 \pm 1,21$, rehidratacijos $-6,77 \pm 0,81$. Reikšmingai pati-
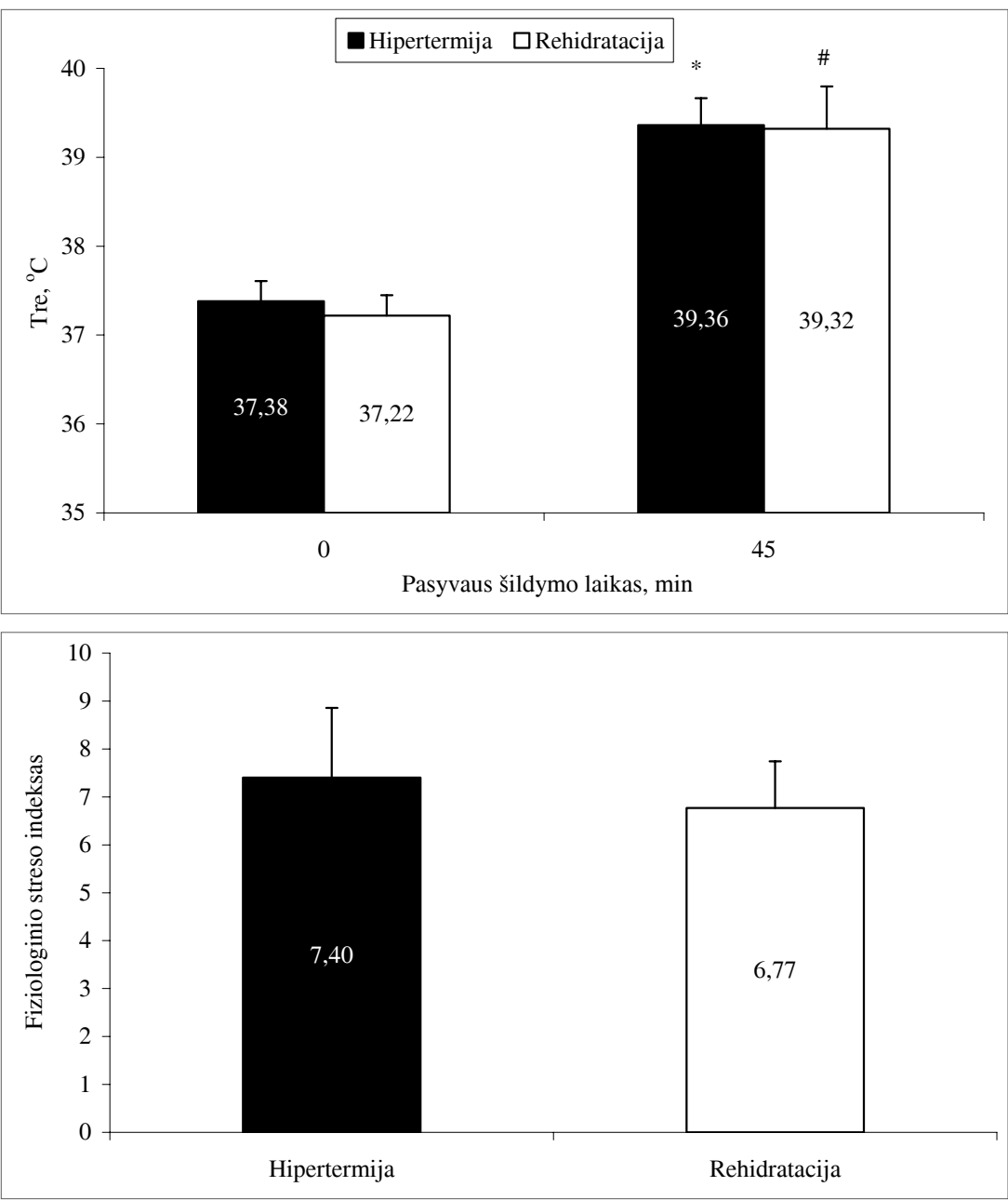

1 pav. Rektalinès temperatūros pokyčiai prieš pasyvų šildymą ir po jo

Pastaba. * \# - p $<0,05$, patikimas rodikliu skirtumas, lyginant su pradine reikšme.

2 pav. Fiziologinio streso indeksas hipertermijos ir rehidratacijos atveju 

kliai atliekant MVJ-2 min - tiesiant blauzdą per kelio sąnarị fiksuotu $120^{\circ}$ kampu
3 pav. Maksimaliosios valingos jègos rodi-
Pastaba. \# - skirtumas tarp kontrolinès reikšmès ir hipertermijos rodikliu $(\mathrm{p}<0,05)$; $\ddagger$ - skirtumas tarp kontrolinès reikšmès ir rehidratacijos rodikliu $(\mathrm{p}<0,05) ;{ }^{*}$ - kontrolinio tyrimo rodikliai, lyginant su pradine reikšme $(p<0,05) ; \neq$ - hipertermijos tyrimo rodikliai, lyginant su pradine reikšme $(\mathrm{p}<0,05) ; \dagger-$ rehidratacijos tyrimo rodikliai, lyginant su pradine reikšme $(\mathrm{p}<0,05)$.

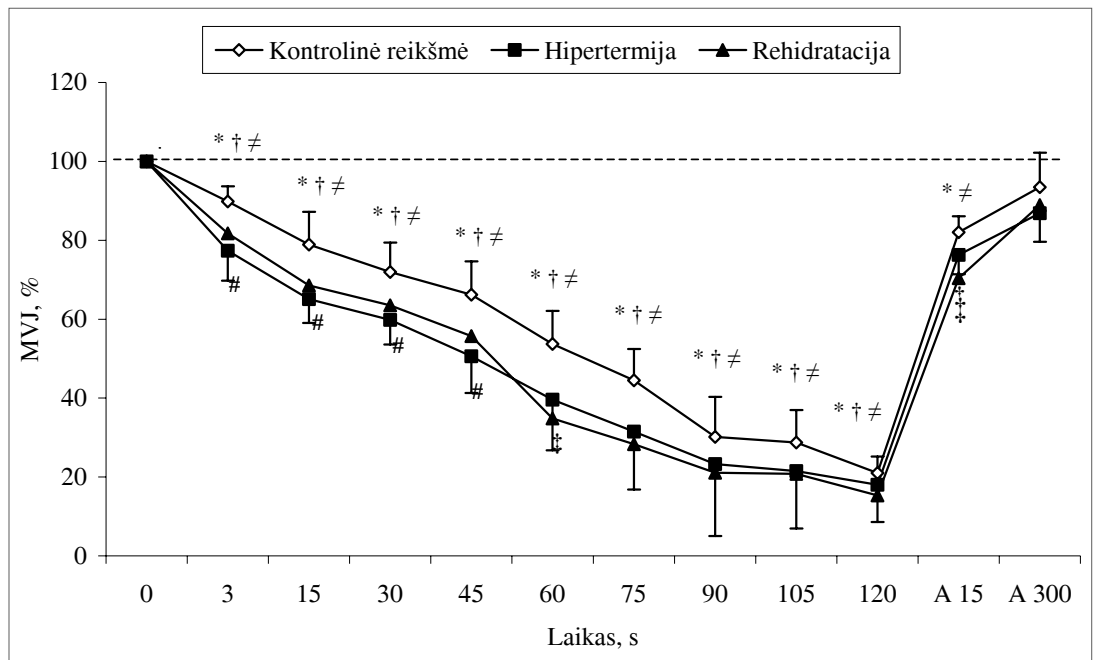

4 pav. Centrinio aktyvavimo rodikliai atliekant MVJ-2 min - tiesiant blauzdą per kelio sąnari fiksuotu $120^{\circ}$ kampu
Pastaba. \# - skirtumas tarp kontrolinès reikšmès ir hipertermijos rodiklių $(\mathrm{p}<0,05)$; * - kontrolinio tyrimo rodikliai, lyginant su pradine reikšme $(\mathrm{p}<0,05) ; \neq$ - hipertermijos tyrimo rodikliai, lyginant su pradine reikšme $(\mathrm{p}<0,05) ; \dagger$ - rehidratacijos tyrimo rodikliai, lyginant su pradine reikšme $(\mathrm{p}<0,05)$.

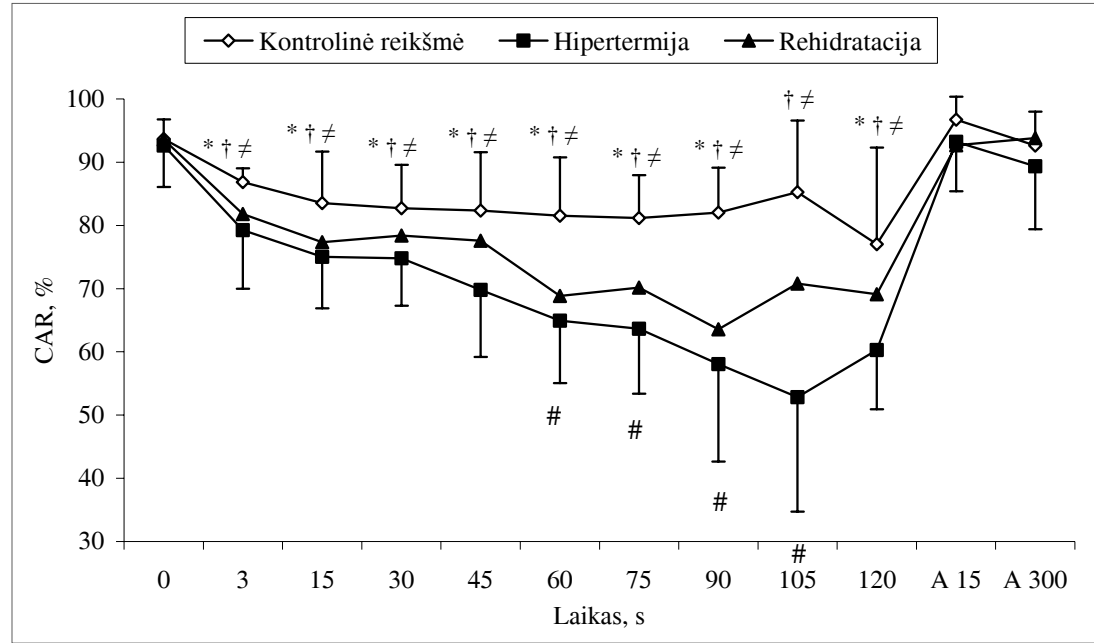

kimo skirtumo tarp vertinamos būsenos rodikliu nenustatyta $(\mathrm{p}>0,05)(2$ pav. $)$.

MVJ krūvio pabaigoje visų tyrimų metu sumažèjo reikšmingai $(p<0,001)$, palyginti su prieš krūvị nustatytais rodikliais. Raumenų izometrinio susitraukimo jèga labiausiai sumažejo hipertermijos ir rehidratacijos eksperimento metu, palyginti su kontroline reikšme. Svarbu paminèti, kad rehidratacija hipertermijos sąlygomis neturejo itakos MVJ-2 min nuovargiui ir atsigavimui, lyginant su hipertermijos eksperimentu. Atsigavimo metu, praejjus $15 \mathrm{~s}$ po krūvio, MVJ buvo tokia pat, kaip ir prieš krūvị. Dviejų veiksnių dispersinė analizė atskleidè, kad analizuojamu jègos rodiklių pokytis priklausė nuo laiko $(\mathrm{p}<0,001)$, o hipertermijos dydžio ir sąveikos tarp jų rezultato reikšmingai nepaveikè ( $\mathrm{p}>0,05)$ (3 pav.).

Išanalizavus valingo aktyvavimo rodiklius pastebèta, kad hipertermija $(\mathrm{p}<0,001)$ ir rehidratacija $(\mathrm{p}<0,05)$ reikšmingai sumažino raumenu centrinès aktyvacijos koeficientą (CAR\%), palyginti su prieš krūvị nustatytu. Rehidratacija hipertermijos sąlygomis MVJ-2 min krūvio pa- baigoje padidino (CAR\%), t. y. buvo sumažintas centrinis nuovargis. Atsigavimo metu, praèjus $15 \mathrm{~s}$ po krūvio, valingo aktyvumo rodikliai grịzo iki prieš krūvị nustatytų rodiklių dydžio. Atlikus dviejų veiksnių dispersinę analizę nustatyta, kad analizuojamų valingo aktyvavimo rodiklių pokytis priklausè nuo laiko $(\mathrm{p}<0,001)$ ir sąveikos tarp būsenos bei laiko ( $p<0,01)$, o būsena rezultato reikšmingai nepaveikè $(\mathrm{p}>0,05)(4$ pav.).

\section{REZULTATŲ APTARIMAS}

Iki šiol literatūroje nepavyko aptikti duomenų, irodančių, koki termini poveiki patiria aktyviai sportuojantys vyrai, kai jiems taikoma A. J. Sergeant (1987) pasyvaus raumenų šildymo metodika. K. Vadopalas ir kt. (2007), taikydami pasyvaus raumenų šildymo metodiką, sukèlè nesportuojančių vyrų organizmo hipertermiją ir $\mathrm{I}^{0}$ dehidrataciją. Panašia metodika šio hipertermijos eksperimento metu ir buvo sukelta organizmo hipertermija (rektalinè kūno temperatūra vidutiniškai padidèjo nuo $37,38 \pm 0,25$ iki $39,36 \pm 0,32^{\circ} \mathrm{C}(\mathrm{p}<0,001)$, 
padidèjo šiluminio streso indeksas FSI) ir $\mathrm{I}^{0}$ dehidratacija (skysčiu netekta iki 1,5\% kūno svorio).

Taip pat neradome duomenų, irodančių, kaip per 45 min pasyviai sukelta hipertermija ir dehidratacija veikia aktyviai sportuojančių vyru raumenų funkcini pajègumą. Padidèjus ašinei kūno temperatūrai iki $38,7^{\circ} \mathrm{C}$ (vidutinio fizinio aktyvumo asmenu) ar $39,2^{\circ} \mathrm{C}$ (didelio meistriškumo asmenu), žmogaus kūnas perkaista, atsiranda nuovargis (Cheung, McLellan, 1998). Hipertermijos eksperimento metu nustatyta, kad hipertermija ir dehidratacija padidino maksimaliosios valingosios jègos nuovargi atliekant MVJ-2 min, ir nustatytas mažesnis centrinès aktyvacijos koeficientas (CAR\%), t. y. atsirado didesnis centrinis nuovargis, palyginti su kontrolinio tyrimo duomenimis. Hipertermijos metu iš centrinès nervu sistemos sumažéjusi motorinių neuronu aktyvacija ir $\mathrm{I}^{\circ}$ dehidratacija greičiausiai paveikè galutinius tyrimo rezultatus.

Mokslininkai naudojosi įvairiais pasyvaus šildymo ir rehidratacijos metodais (rektalinè temperatūra iki $39,5^{\circ} \mathrm{C}$ buvo pasiekiama per $110 \mathrm{~min}$, tiriamieji suvartodavo apie 1,4 1 skysčiu (Thomas et al., 2006)). Kol kas nèra aišku, kaip rehidratacija hipertermijos sąlygomis veikia aktyviai sportuojantčių vyrų MVJ ir centrinį nuovargi, atliekant maksimalaus intensyvumo izometrinius pratimus.

Rehidratacijos eksperimento metu netektam skysčiui atgauti tiriamieji gèrè fiziologini $(0,9 \%$ $\mathrm{NaCl}) 37^{\circ} \mathrm{C}$ (kūno temperatūros) tirpalą. Atlikus peroralinę rehidrataciją hipertermijos sąlygomis, tiriamuju kūno svoris vidutiniškai padidejo $0,1 \pm 0,42 \mathrm{~kg}$, ir tai sudare $0,1 \pm 0,58 \%$ jų kūno svorio. Tai rodo, kad tiriamieji iki maksimalaus krūvio pradžios visiškai atgavo iš organizmo pašalinto skysčio kieki.

Šio eksperimento metu nustatyta, kad rehidratacija hipertermijos sąlygomis neturejo įtakos MVJ nuovargiui ir atsigavimui, palyginti su hipertermijos eksperimentu, tačiau krūvio pabaigoje nustatytas didesnis (CAR\%), t. y. buvo sumažintas centrinis nuovargis atliekant MVJ-2 min. Galima manyti, kad tai iš dalies priklauso nuo fiziologinio $\mathrm{NaCl} 0,9 \% 37^{\circ} \mathrm{C}$ temperatūros tirpalo temperatūros, jo patekimo i kraujotakos sistemą, biocheminių mechanizmų pokyčiu, skysčiu rezorbcijai panaudotos energijos sunaudojimo. Dèl peroralinès rehidratacijos galejo pakisti vandens, natrio, kalio pusiausvyra viduląstelinèje ir tarpląstelinèje terpejje. Pastarieji elektrolitai žmogaus organizme yra laikomi pagrindiniais, kuriu dèka palaikoma vandens pusiausvyra viduląsteli- nëje bei tarpląstelinėje terpèje, nervinis laidumas, ląstelinis metabolizmas ir kraujo tūris - osmoreguliacija ir spaudimas (Armstrong, 2000). Dèl to galejjo pasikeisti impulso dažnis motoriniame vienete, reikalingas tetaniniam susitraukimui (Todd et al., 2004), ir sumažèti centrinis nuovargis. Peroralinè rehidratacija galejo padidinti cirkuliuojančio kraujo tūrí, dèl to sulètėjo širdies veikla, tuo pačiu sumažejo FSI ir centrinis nuovargis. Gauti rezultatai sutampa su kitu mokslininkų gautaisiais, irodančiais, kad hipertermija sumažina valinga jègą ir centrinès aktyvacijos koeficientą (CAR\%), atliekant ištvermès reikalaujančius fizinius pratimus. L. Nybo ir B. Nielsen (2001) tyrimu irode, kad hipertermijos metu (rektalinè temperatūra $\sim 39,7^{\circ} \mathrm{C}$ ) MVJ izometrinè raumenu jèga po 2 min nenutrūkstamo krūvio sumažèjo $58 \%$, o centrinès aktyvacijos koeficientas $-54 \%$, palyginti su kontroline reikšme. Šio tyrimo metu krūvio pabaigoje MVJ izometrinè raumenu jèga sumažèjo $78 \%$, centrinès aktyvacijos koeficientas - 40\%, palyginti su kontroline reikšme. K. Vadopalas ir kt. (2007) tyrimu irodè, kad rehidratacija hipertermijos metu gali padidinti nesportuojančiu vyru centrini nuovargi, atliekant 2 min maksimalų izometrini krūvị. Šiuo atveju fiziologinio terminio streso atsakas ir centrinis nuovargis galèjo sumažèti dèl geresnès aktyviai sportuojančių vyrų širdies ir kraujagyslių sistemos adaptacijos prie hipertermijos ir fiziniu krūvių, geresnio vandens ir elektrolitų santykio prakaite, viduląstelinejje ir tarpląstelinejje terpèje, palyginti su nesportuojančiais vyrais (Armstrong, 2000).

Manome, kad aktyviai sportuojančių vyrų organizmo centrini nuovargi lemia daugybè veiksnių, tarp kurių neabejotinai yra rehidratacijos fiziologiniai mechanizmai, širdies ir kraujagysliu sistemos adaptacija prie fizinių krūvių ir hipertermijos.

\section{IŠVADOS}

1. Hipertermijos ir rehidratacijos eksperimentu metu MVJ nuovargis kito vienodai.

2. Hipertermija padidino centrini nuovargi.

3. Rehidratacija hipertermijos salygomis teigiamai veikè organizmą ir sumažino centrini nuovargi. 


\title{
LITERATŪRA
}

Armstrong, L. E., Curtis, W. C., Hubbard, R. W. et al. (1992). Symptomatic hyponatremia during prolonged exercise in heat. Medicine \& Science in Sport \& Exercise, $25,543-549$

Armstrong, L. E., Hubbard, R. W., Jones, B. H., Daniels, J. T. (1986). Preparing Alberto Salazar for the heat of the 1984 Olympic marathon. The Physician and Sport Medicine, 14, 73-81.

Armstrong, L. E. (2000). Performing in Extreme Environments: The Importance of Dietary Sodium. Human Kinetics. P 38-45.

Cheung, S. S., McLellan, T. M. (1998). Comparison of short-term aerobic training and high aerobic power on tolerance to uncompensable heat stress. Aviation, Space, and Environmental Medicine, 70 (7), 637-643.

Cheung, S. S., Sleivert, G. G. (2004). Multiple triggers for hyperthermia fatigue and exhaustion. Journal of Exercise and Sport Sciences Reviews, 100-106.

Coyle, E. F., Hamilton, M. A. (1990). Fluid replacment during exercise: Effects on physiological homeostasis and performance. In: C. V. Gisolfi \& D. R. Lamb (Eds.), Fluid Homeostasis During Exercise. Perspectives in Exercise Science and Sports Medicine, 3, 281-308. Carmel, IN: Benchmark Press.

Enoka, R. M. (2002). Neuromechanics of Human Movement. $3^{\text {rd }}$ edition. Champaign, IL: Human Kinetics.

Kent-Braun, J. A. (1999). Central and peripheral contributions to muscle fatigue in humans during sustained maxinal effort. European Journal of Applied Physiology, $80,57-63$.

Moran, D. S., Shitzer, A., Pandolf, K. B. (1998). A physiological strain index to evaluate heat stress. Ambient Journal of Physiology, 275, R 129-134.
Morrison, S. A., Sleivert, G. G., Cheung, S. S. (2004).

Passive hyperthermia reduces voluntary activation and isometric force production. European Journal of Applied Physiology, 91, 729-736.

Nybo, L., Nielsen, B. (2001). Hyperthermia and central fatigue during prolonged exercise in human. Journal of Applied Physiology, 91, 1055-1060.

Proulx, C. I., Ducharme, M. B., Kenny, G. P. (2003). Effect of water temperature on cooling efficiency during Hyperthermia in humans. Journal of Applied Physiology, $94,1317-1323$

Rowell, L. B. (1974). Human cardiovascular adjustments to exercise and thermal stress. Physiological Review, 54, $75-159$.

De Ruiter, C. J., De Haan, A. (2000). Temperature effect on the force / velocity relationship of the fresh and fatigued human adductor pollicis muscle. European Journal of Physiology, 440, 163-170.

Sargeant, A. J. (1987). Effect of muscle on leg extension force and short-term power output in humans. European Journal of Applied Physiology, 56, 693-698.

Thomas, M. M., Cheung, S. S., Elder, G. C., Sleivert, G. G. (2006). Voluntary muscle activation is impaired by core temperature rather than local muscle temperature. Journal of Applied Physiology, 100, 1361-1369.

Todd, G., Butler, J. E., Taylor, J. L., Gandevia, S. C. (2004). Hyperthermia: A failure of the motor cortex and the muscle. Journal of Physiology, 563 (2), 621-631.

Vadopalas, K., Skurvydas, A., Brazaitis, M. ir kt. (2007). Hipertermijos ir dehidratacijos įtaka griaučių raumenu nuovargiui atliekant maksimalaus intensyvumo izometrinius pratimus. Ugdymas. Kūno kultūra. Sportas, 4 (67), $87-93$

\section{IMPACT OF HYPERTHERMIA AND DEHYDRATION ON THE SKELETAL MUSCLE FATIGUE OF ACTIVELY ENGAGED IN SPORTS MEN PERFORMING ISOMETRIC EXERCISES OF MAXIMUM INTENSITY}

\author{
Kazys Vadopalas, Albertas Skurvydas, Marius Brazaitis, Laimutis Škikas, \\ Dalia Mickevičienè, Ieva Lukošiūtè-Stanikūnienè \\ Lithuanian Academy of Physical Education, Kaunas, Lithuania
}

\begin{abstract}
The aim of the study was to establish the impact of hyperthermia and dehydration and to evaluate the impact of rehydration on the functions of skeletal muscles performing 2 min maximum intensity isometric load under the conditions of hyperthermia. The research participants were male adults actively engaged in sports $(\mathrm{n}=10)$, aged $21 \pm 1.3$ years, with body mass of $70.46 \pm 6.54 \mathrm{~kg}$, and height $-174 \pm 5.3 \mathrm{~cm}$.

Three studies were carried out - one control study and the other two - experimental. During the first experiment the bodies of the research participants experienced hyperthermia and dehydration (research
\end{abstract}


participants kept their legs up to the pelvis in the bath with hot water $\left(44 \pm 1^{\circ} \mathrm{C}\right)$ for 45 minutes). During the other experiment, using the same methods of increasing hyperthermia, the organisms experienced peroral rehydration with the $1000 \mathrm{ml}$ solution of $37^{\circ} \mathrm{C} \mathrm{NaCl} 0.9 \%$. The load of maximum voluntary strength (MVS) lasted for 120 seconds, every 15 seconds the muscle was stimulated by electrical impulses - the duration of the stimulation was $250 \mathrm{~ms}$, the frequency was $100 \mathrm{~Hz}$, and the voltage was $85-105 \mathrm{~V}$. We registered the moment of MVS $\left(\mathrm{N}^{*} \mathrm{~m}\right)$ and the degree of central activation ratio of muscles CAR $\%=\mathrm{MVS} /(\mathrm{MVS}+$ electrical impulse) $\times 100$. When the load was applied the research participants were motivated verbally, and they were provided with the visual feedback of changes in strength signals.

After hyperthermia and dehydration was applied, the rectal body temperature averagely increased from $37.38 \pm 0.25$ to $39.36 \pm 0.32^{\circ} \mathrm{C}(\mathrm{p}<0.001)$, applying rehydration under the conditions of hyperthermia it was from $37.22 \pm 0.25$ to $39.32 \pm 0.4^{\circ} \mathrm{C}(\mathrm{p}<0.001)$. During the hyperthermia experiment the research participants lost $0.93 \pm 0.32 \mathrm{~kg}$ on average, and that was $1.17 \pm 0.4 \%$ of their body mass ( $\mathrm{I}^{\circ}$ dehydration). Having analyzed the physiological index of heat stress (in the 10 point system) we established that the research participants experienced high level physiological stress - in the case of hyperthermia it was $7.40 \pm 1.21$, and in the case of rehydration $-6.77 \pm 0.81$. At the end of the load the MVS decreased significantly in all the cases $(\mathrm{p}<0.001)$, compared to the indices which were established before the load. After 15 seconds during the recovery time the strength regained the level which was established before the load was applied. Two-factor dispersion analysis revealed that the changes in the analyzed strength indices depended on time $(p<0.001)$; however, the level of hyperthermia and their interaction did no impact the results $(\mathrm{p}>0.05)$. After the analysis of the indices of voluntary activation we noticed that hyperthermia $(p<0.001)$ and rehydration $(p<0.05)$ significantly decreased the degree of central activation ratio CAR\% compared to the one established before the load. During the recovery time, 15 seconds after the application of the load, the strength index of central activation regained the level which was before the load. The two-factor dispersion analysis allowed us to establish that the changes in the strength indices of voluntary activation depended on time $(p<0.001)$, the interaction between the condition and time $(\mathrm{p}<0.01)$, and the condition did not significantly affect the result $(p>0.05)$. Applying the methods of passive heating of muscles the research participants were made to experience hyperthermia and $\mathrm{I}^{\circ}$ dehydration. Hypertension increased the central fatigue. During the experiments of hyperthermia and dehydration MVS fatigue altered at the same level. Under the conditions of hyperthermia rehydration had a positive impact on the central fatigue and decreased it even more when the 2 min maximum isometric load was performed.

Keywords: hyperthermia, isometric exercises, dehydration, rehydration, central fatigue. 